\title{
Domestic and Sexual Violence Related Asylum Claims in the Refugee Review Tribunal
}

\author{
Amanda Joyce Neilson
}

Domestic Violence-based Asylum Claims (DVAC) fall within a vexed area of Australian refugee law, which has been subject to significant academic and policy attention. Currently, an asylum bid by a victim of domestic violence for a Protection (Class XA) Visa turns on three elements: the membership of the claimant of a 'particular social group' (PSG), which is one of the five grounds listed as a prerequisite to refugee status in the 1951 Convention Relating to the Status of Refugees ('the Refugees Convention'); ${ }^{1}$ a nexus between that PSG and the harm suffered by the claimant; and, an inability or unwillingness of the state in question to assist. The final requirement ensures that the harm meets the threshold set by the Refugees Convention, and is not a purely personal form of harm.

This essay reviews two decisions of the Refugee Review Tribunal, arguing that they demonstrate a reticence on the part of the Australian judiciary to provide a definitive legal ruling on the legitimacy of asylum claims for domestic violence, perpetrated by non-state actors. Using comparative legal analysis, the essay contends that while this approach is allied with the trends set by other Commonwealth jurisdictions, the Australian approach remains unique. It argues that the preference for guidelines and a policy of case-by-case assessment allows for a degree of flexibility in the assessment of claims in this area of refugee law to provide protection to those who may not have been able to seek it otherwise. The essay demonstrates, however, that this ambiguity can lead to practical difficulties for claimants in navigating such a broad scheme, particularly with regard to identifying their membership of a PSG and the giving of evidence in tribunal hearings.

\section{Relevant Law and Issues to Consider}

The relevant section of the Migration Act 1958 (Cth), s 36(2), provides that a Protection (Class XA) Visa may be granted to a 'non-citizen in Australia to

1 Convention Relating to the Status of Refugees (Refugees Convention), opened for signature 28 July 1951, 189 UNTS 150 (entered into force 22 April 1954). 
whom the Minister is satisfied that Australia has protection obligations under the Refugees Convention as amended by the Refugees Protocol.' ${ }^{2}$ Article 1A(2) of the Refugees Convention defines a refugee as someone who:

owing to well founded fear of being persecuted for reasons of race, religion, nationality, membership of a particular social group or political opinion, is outside the country of his nationality and is unable or, owing to such fear, is unwilling to avail himself of the protection of that country. ${ }^{3}$

In order to be classified as a refugee, an applicant must be outside of his or her country, have a well-founded fear of persecution, fall into one of the five convention grounds and a nexus must exist between that ground and the persecution. Note that gender is not mentioned specifically in the convention.

\section{A The Definition of 'Persecution'}

While the Refugees Convention does not provide a definition of persecution, it is widely acknowledged that the convention is 'primarily aimed at the protection of individuals from the state of public forms of persecution, rather than intruding into the private realm' ${ }^{4}$ Domestic violence is largely perpetrated by non-state actors for non-convention reasons, which raises the question as to whether victims of such violence are eligible to claim asylum under the Refugees Convention in the first place.

This question was answered by the High Court in Minister for Immigration and Multicultural Affairs $v$ Khawar. ${ }^{5}$ In separate judgments, the majority agreed that where serious harm is inflicted by non-state actors for a non-convention reason, the nexus to the Refugees Convention will be met if the state in question withholds protection in a selective and discriminatory manner. Justice Kirby, following the decision of the English House of Lords in Islam $(A P) v$ Secretary of State for the Home Department Regina $v$ Immigration Appeal Tribunal and Another Ex Parte Shah (AP) (Conjoined Appeals) ${ }^{6}$ applied the formula, 'Persecution $=$ Serious Harm + The Failure of State Protection' ${ }^{7}$ Chief Justice Gleeson held that persecution may be found where criminal conduct in a private context is condoned or tolerated by the state in situations where the state has a duty to provide protection from such conduct. ${ }^{8}$

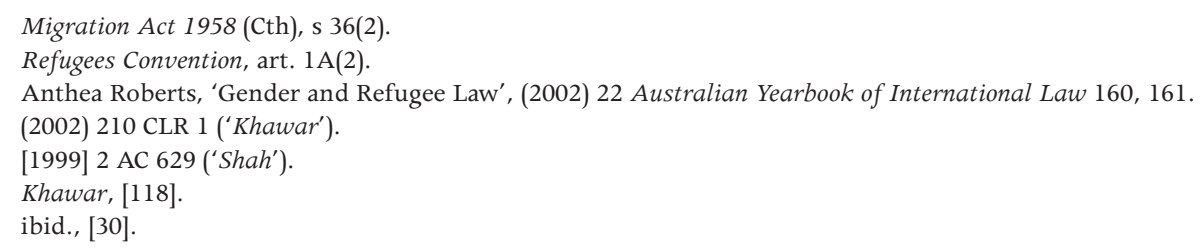


Post-Khawar, the Migration Act was amended to insert s 91R, which purported to limit the definition of 'persecution' under the Refugees Convention. This amendment was made to ensure that the Khawar decision did not widen the application of the Refugees Convention 'beyond the bounds intended'. ${ }^{9}$ The section qualifies the term 'persecution', stating that Article 1A(2) does not apply in relation to persecution for a convention ground unless:

- the reason for the persecution is 'the essential and significant reason' ${ }^{10}$

- the persecution involves 'significant harm to the person', ${ }^{11}$ and

- the persecution 'involves systematic and discriminatory conduct'. ${ }^{12}$

The amendment also provided a list of examples of 'serious harm' to include a threat to a person's life or liberty, significant physical harassment and/or illtreatment, and economic hardship or denial of capacity to earn a livelihood that threatens a person's capacity to subsist. ${ }^{13}$ The list is non-exhaustive, however, and thereby allows for a degree of judicial discretion, as demonstrated by the following case studies.

\section{B Membership of a Particular Social Group}

In Applicant Sv Minister for Immigration and Multicultural Affairs, ${ }^{14}$ the High Court defined a PSG as follows:

First, the group must be identifiable by a characteristic or attribute common to all members of the group. Secondly, the characteristic or attribute common to all members of the group cannot be the shared fear of persecution. Thirdly, the possession of that characteristic or attribute must distinguish the group from society at large. ${ }^{15}$

In the case of family groups, whose claims rest on the fact that they themselves constitute a PSG, s 91S of the Migration Act states that a decision-maker must 'disregard any fear of persecution ... that any other or former member ... of that family has ever experienced', where that reason is not mentioned in Article $1 \mathrm{~A}(2)$ of the Refugees Convention. ${ }^{16}$

Whether a group is a PSG for the purposes of the Refugees Convention is dependent upon relevant information regarding legal, social, cultural and

9 Explanatory Memorandum, Migration Legislation Amendment Bill (No 6) 2001 (Cth), 18.

10 Migration Act 1958 (Cth), s 91R(1)(a).

11 ibid., s $91 \mathrm{R}(1)(\mathrm{b})$.

12 ibid., s 91R(1)(c).

13 Migration Act 1958 (Cth) s 91R(2).

14 (2004) 217 CLR 387.

15 ibid., [36] (Gleeson CJ, Gummow and Kirby JJ).

16 Migration Act 1958 (Cth) s 91S. 
religious norms in their country of origin. ${ }^{17}$ Gender has previously been acknowledged by Australian courts as a PSG, ${ }^{18}$ however, the courts are swift to qualify these findings by stating that each case turns on its individual facts, and that analogy is not to be relied upon in the decision-making process. ${ }^{19}$

\section{Nexus to the Refugee Convention}

It is now well established in Australian jurisprudence that the nexus to the convention will be sufficient if a state is unable or unwilling to protect those suffering from persecution at the hands of non-state actors..$^{20}$ Of course, this does not mean that every victim of domestic violence is now able to successfully obtain refugee status. As Bacon and Booth argue, 'While violence against women may exist in most if not all cultures, its prevalence is certainly not uniform ... and [it] certainly does not always receive the tacit acceptance of the state' ${ }^{21}$ There is a significant evidentiary burden placed on an applicant, as 'decision-makers are entitled to assume (unless the contrary is proved) that the state is capable within its jurisdiction of protecting an applicant ${ }^{\prime 22}$ In such situations, the courts must rely heavily on the socio-legal and political context and country information, alongside the particular claims of the applicant to make such determinations. ${ }^{23}$

\section{The Two Cases}

\section{Case 124: Domestic Violence in Papua New Guinea}

The applicant applied for asylum in Australia to escape over 20 years of domestic violence and sexual abuse at the hands of her husband in Papua New Guinea. The applicant feared death or infection with HIV by her husband. She

\footnotetext{
17 Khawar, [26] (Gleeson CJ).

18 See Minister for Immigration and Multicultural Affairs $v$ Cali [2000] FCA 1026; Thalary $v$ Minister for Immigration and Ethnic Affairs (1997) 72 FCR 437; Minister for Immigration and Multicultural Affairs $v$ Ndege (2000) 59 ALD 758; SZAIX v Minister for Immigration and Multicultural and Immigrant Affairs [2004] FCA 104; and SZAQK v Minister for Immigration and Multicultural and Immigrant Affairs [2004] FMCA 407.

19 Khawar, [26] (Gleeson CJ).

20 ibid.

21 Rachel Bacon \& Kate Booth, 'Persecution by Omission: Vioence by Non-State Actors and the Role of the State under the Refugees Convention in Minister for Immigration and Multicultural Affairs $v$ Khawar' (2002) 24 Sydney Law Review 548, 600.

22 Khawar, [115] (Kirby J) citing Canada (Attorney General) $v$ Ward [1993] 2 S.C.R. 689, 724-26.

23 Australian Law Reform Commission (ALRC), Family Violence and Commonwealth Laws - Immigration Law, Issues Paper No 37 (2011), 109.

$24 \quad 1200137$ [2012] RRTA 779 (1 October 2012).
} 
claimed that though she had sought assistance on a number of times previously, authorities in Papua New Guinea were consistently unwilling to protect her because she was a woman, and considered her husband's property. ${ }^{25}$

The tribunal determined that the "violent beatings and sexual violence clearly satisfied the definition of "serious harm" amounting to persecution' ${ }^{26}$ under $\mathrm{s}$ 91R of the Migration Act. In their determination of the applicant's status as a member of a PSG group, they referenced extensive country information to support the applicant's claims. The tribunal determined that the country

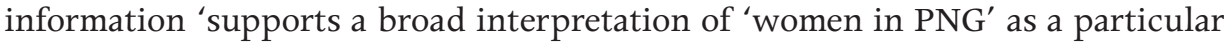
social group, 'as the discriminatory and abusive treatment of women in PNG is pervasive'.${ }^{27}$ They determined on the evidence that the applicant had been

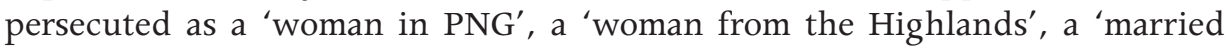

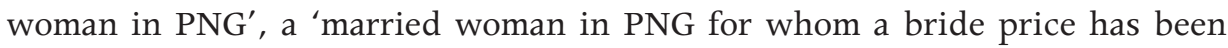
paid' and as a 'woman subject to domestic violence in $\mathrm{PNG}^{\prime}{ }^{28}$ As the fear of harm at the hands of her husband was both continuing and not remote, the tribunal determined that the applicant met the convention nexus requirement.

Finally, the tribunal found that the applicant could not rely on state or police protection, noting the attitude of impunity towards domestic violence incidents in Papua New Guinea. This finding was based on country information, which indicated, 'The police in PNG are unable to protect women and are complicit in the persecution of female victims of domestic violence' ${ }^{29}$ The tribunal determined that the applicant should be granted refugee status on the basis of persecution for reasons of her membership of the particular social group 'women in $\mathrm{PNG}^{\prime}{ }^{30}$

\section{Case $2^{31}:$ Interfamilial Rape in Fiji}

The applicant, a Fijian-Indian woman, applied for asylum in Australia after being raped twice by her stepmother's brother. She claimed that the authorities had taken no action to pursue her case, that her abuser had 'contacts' in the police force that prevented such action, and that she feared continuation of the sexual violence upon her return to Fiji as she had 'nowhere else to go' but back to her stepmother and abuser. ${ }^{32}$ The applicant did not submit as part of her claim that she was a member of any PSG.

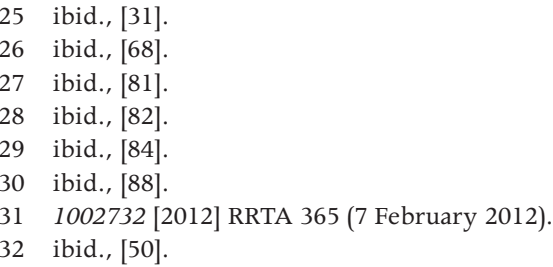


The tribunal determined that 'repeated sexual violence with intimidation and threats to kill the applicant should she report the crimes to the police ${ }^{\prime 33}$ constituted 'significant ill-treatment of the person', thus falling within the definition of serious harm, s 91R of the Migration Act. As the applicant's stepmother's brother perpetrated the rapes, the tribunal needed to seriously consider whether the harm was aimed at the applicant as an individual, and not for a convention reason. The tribunal determined that there was nothing to suggest that the rape was anything other than a 'crime of opportunity perpetrated on the applicant as a weaker, more vulnerable person who happened to be home alone and unprotected' at the time of the rapes.

The tribunal determined that the applicant was a member of the particular social group 'unprotected single Indian-Fijian women with no family support'. Referencing extensive country information, the tribunal determined that the applicant's gender, ethnicity and lack of familial support in Fiji were all significant reasons for her persecution. They acknowledged that it was difficult to make a definitive finding on whether police protection would be withheld from the applicant. They determined, however, that from the evidence presented, 'the current authorities of Fiji will not afford the applicant effective state protection from the threat of sexually violent crimes' ${ }^{34}$ The applicant was therefore granted asylum on the ground of her fear of serious physical harm for reason of her membership of the particular social group: 'unprotected single Indian-Fijian women with no family support'.

\section{Comparative Analysis of the Australian Approach}

\section{A Persecution, the Convention Nexus and the Public/ Private Dichotomy in Refugee Law}

The Australian courts have demonstrated a willingness to take a holistic approach to the reconciliation of domestic violence-related asylum claims with the requirements of the Refugees Convention. Domestic violence is generally perpetrated in the private sphere, which on face value creates difficulty in reconciling the private nature of the harm with the traditionally public nature of persecution imagined under the Refugees Convention. ${ }^{35}$ The Khawar decision emulates the broader jurisprudential trend throughout Commonwealth countries

33 ibid., [74]

34 ibid., [89].

35 Roberts, 'Gender and Refugee Law', 160, 161. 
that persecution at the hands of non-state actors will fall within the convention requirements 'in situations where the State is unable or unwilling to afford effective protection against such harm'. ${ }^{36}$ This acknowledges that persecution is not exclusive to the public sphere, and that private harm by non-state actors can lead to serious abuse of the human rights of victims of domestic violence.

The landmark ruling on this issue was made by the House of Lords in Shah.$^{37}$ In this case, two married Pakistani women sought asylum in the United Kingdom for fear that, if they returned to Pakistan, they would be beaten by their husbands and potentially prosecuted for adultery. The penalties for adultery include flogging or being stoned to death. Lords Hoffman and Steyn held that harm caused by a non-state actor could constitute persecution where there was an inability or unwillingness on the part of the State to provide effective protection, for reasons of membership of a gender-defined particular social group. ${ }^{38}$ Steyn stated, 'Given the central feature of state-tolerated and state-sanctioned gender discrimination, the argument that the appellants fear persecution not because of membership of a particular social group but because of the hostility of their husbands is unrealistic' ${ }^{39}$

The Shah precedent was refined by a decision of the New Zealand Refugee Status Appeals Authority (RSAA) in 2000. In Refugee Appeal No. 71427/99, Haines QC found that the applicant, an Iranian woman seeking asylum for fear of further violence from her abusive husband, was trapped in a system of 'statesanctioned inequality ... in the context of the Islamic theocratic regime', ${ }^{40}$ and that this constituted persecution within the confines of the Refugees Convention. Haines QC 'unpacked and made explicit many of the underlying assumptions of Shah, creating a framework both practically and theoretically coherent for analysing persecution and the relationship between non-State actor agency and state responsibility' ${ }^{41}$ The decision continued the trend of applying a 'holistic understanding of refugee status and protection' ${ }^{\prime 2}$ within the context of domestic violence-related asylum claims.

In Khawar, the High Court acknowledged both Shah and Refugee Appeal No. $71427 / 99$ in its decision to grant asylum to the appellant. Of particular importance is the judgment of Gleeson CJ, who stated that persecution can

\footnotetext{
36 Alice Edwards, 'Age and Gender Dimensions in International Refugee Law', in Erika Feller, Volker Turk and Frances Nicholson (eds), Refugee Protection in International Law: UNHCR's Global Consultations on International Protection (Cambridge University Press) 46, 59.

37 [1999] 2 AC 269 ('Shah').

38 ibid., 558 (Lord Steyn); 564-65 (Lord Hoffman).

39 ibid., 558 (Lord Steyn).

40 Refugee Status Appeals Authority (RSAA), 16 August 2000, [7].

41 Deborah Anker, 'Refugee Status and Violence Against Women in the "Domestic" Sphere: The Non-State Actor Question' (2001) 15 Georgetown Immigration Law Journal 391, 396.

42 ibid., 397.
} 
be based on the 'combined effect' of multiple agents. ${ }^{43}$ He reasoned that in the context of state-sanctioned domestic violence - which prima facie may be perpetrated for a non-convention reason - the nexus requirement will be satisfied if at least one agent of persecution (state or individual) persecutes the victim for a convention reason. He stated:

Where persecution consists of two elements, the criminal conduct of private citizens, and the toleration or condonation of such conduct by the state or agents of the state, resulting in the withholding of protection which the victims are entitled to expect, then the requirement that the persecution be by reason of one of the Convention grounds may be satisfied by the motivation of either the criminals or the state. ${ }^{44}$

The willingness of the Australian Refugee Review Tribunal to take full advantage of this broad mandate is evidenced by the case studies presented above. In Case 1 the systemic nature of both the abuse and refusal of PNG authorities to provide protection to the applicant meant that her claim can easily fit into the framework above. Case 2 proved more problematic for the tribunal in its decision as to whether the applicant met the persecution and nexus requirements for asylum. In Case 2, the tribunal granted asylum to the applicant, even in the face of uncertainty as to whether the Fijian police force would in fact refuse to take action against her abuser. They considered not only her immediate reasons for seeking asylum, but also her personal situation and the context in which she was seen in Fijian society as a whole. The PSG to which she was ascribed - an 'unprotected single Indian-Fijian women with no family support' - intimates that the tribunal sought to combine gender, race and personal circumstances in order to create a situation in which each of the convention requirements were met.

The precedents set in the above cases have also, notably, begun to permeate the bureaucratic processes before asylum claims reach the tribunal stage. The recent revision of the Department of Immigration and Border Control's guidelines for assessing gender-related asylum claims now acknowledges that 'Sexual violence and harm perpetrated in the "private" sphere or by nonstate agents can ... amount to persecution', and that 'state protection may be withheld for a Convention reason ... [which can] amount to persecution under the Refugees Convention'. ${ }^{45}$

43 Khawar, [27] (Gleeson CJ).

44 ibid., [31] (Gleeson CJ).

45 Department of Immigration and Border Security, 'PAM3 Guidelines: Gender-Related Asylum Claims', [16.2]. 


\section{B The Particular Social Group Convention Ground}

The PSG convention ground is 'regarded as the most amorphous of all the Convention grounds', ${ }^{46}$ and has proven problematic in both domestic and international jurisprudence. Australia has favoured a broad approach when interpreting the ground, following decisions from other Commonwealth jurisdictions including Canada and New Zealand. Each of these jurisdictions' interpretations of the convention ground have reflected the two 'dominant approaches' espoused by the United Nations Commissioner for Refugees (UNHCR) in its guidelines for the interpretation of PSG. ${ }^{47}$

The UNHCR guidelines for the interpretation of PSG recommend that the following definition should be adopted:

A particular social group is a group of persons who share a common characteristic other than their risk of being persecuted, or who are perceived as a group by society. The characteristic will often be one which is innate, unchangeable, or which is otherwise fundamental to identity, conscience or the exercise of one's human rights. ${ }^{48}$

The two dominant approaches are summarised by Kneebone as the 'protected characteristics' approach and the 'social perception' approach, which 'recognise respectively both the internal unifying characteristics of the group and the external perception or visibility of the group' ${ }^{49}$

Both Canada and New Zealand have applied a broad interpretation of a PSG to include women fleeing persecution ${ }^{50}$ and women of Iran, ${ }^{51}$ for example. In Canada (Attorney General) $v$ Ward $^{52}$ the Supreme Court of Canada outlined three categories of PSG. These were (1) 'those defined by an innate or unchangeable characteristic, for example individuals fearing persecutionby reason of gender'; (2) 'those whose members voluntarily associate for reasons so fundamental to their human dignity that they should not be forced to forsake the association'; and, (3) 'those associated by a former voluntary status, unalterable due to its historical permanence' ${ }^{53}$

\footnotetext{
46 Susan Kneebone, 'Women Within the Refugee Construct: 'Exclusionary Inclusion' in Policy and Practice — the Australian Experience' (2005) 17(1) International Journal of Refugee Law 7, 26.

47 United Nations Commissioner for Refugees (UNHCR), Guidelines on International Protection: 'Membership of a Particular Social Group' Within the Context of Art. 1A(2), UN doc. HCR/GIP/02/02, 7 May 2002.

48 ibid., B, [11].

49 Kneebone, 'Women Within the Refugee Construct', 27.

50 Mayers and Marcel $v$ MEI (1992), 97 DLR (4th) 729 (FCAD).

51 Refugee Appeal No. 71427/99

52 [1993] 2 SCR 689.

53 ibid., 739.
} 
Similarly, in Refugee Appeal no 71427/99,54 the NZ RSAA held that 'women of Iran' were a PSG on the basis that the 'overarching characteristic of those fundamentally disenfranchised and marginalised by the state is the fact that they are women'.$^{55}$ Mullally argues that by broadly interpreting the convention to include 'women of Iran', '[t]he case goes beyond the more limiting, and in some cases tautological, claims that the social group must be limited further, for example to women who are at risk of spousal or intimate partner abuse' ${ }^{56}$ She states that in assessing the reasons for persecution in this case, '[g]ender is recognised as the relevant variable'..$^{57}$

In Khawar, the majority agreed that 'women in Pakistan' constituted a particular social group; yet each judge favoured a slightly different approach. Gleeson CJ made the broadest interpretation, arguing that there was 'nothing inherently implausible in the suggestion that women in a particular country may constitute a persecuted group' ${ }^{58}$ Kirby J stated that ' $[\mathrm{t}]$ here may be a particularly vulnerable group of married women in Pakistan, in dispute with their husbands ... unable to call on male support ${ }^{\prime},{ }^{59}$ while McHugh and Gummow JJ suggested that at its narrowest, the group might be categorised as 'married women in a household that did not include a male blood relation to whom the woman might look for protection against violence by the members of the household' ${ }^{60}$

Crucially, Gleeson CJ emphasised that each decision must be decided on its facts, and that the decision-makers must take into account the particular context within which the asylum claim is made. He states:

An Australian court or tribunal would need to be well-informed about the relevant fact and circumstances, including cultural conditions, before reaching a conclusion that what occurs in another country amounts to persecution by reasons of the attitudes of the authorities to the behaviour of private individuals. ${ }^{61}$

The High Court's reluctance to narrow the definition of PSG and emphasis on case-by-case assessment practice has allowed lower courts and tribunals to make nuanced assessments on the basis of the facts of each case, while managing the legislative requirements under the Migration Act. This is reflected in the two case studies above. In Case 1, even though narrower potential PSGs were presented

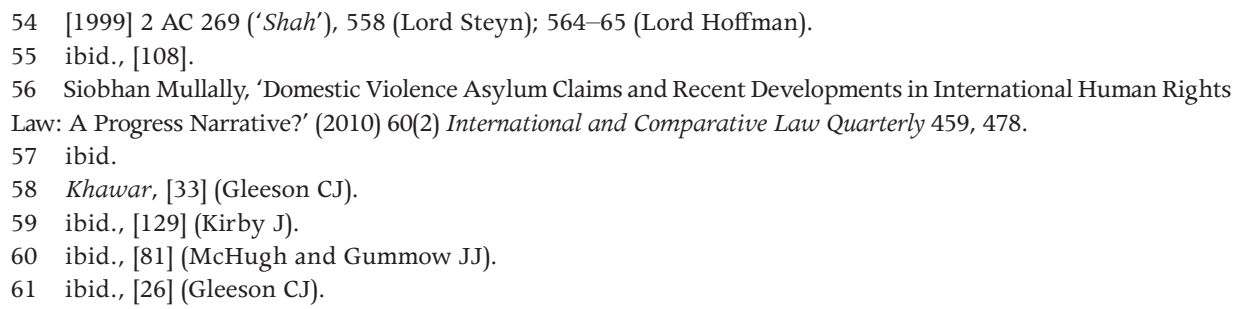


to the tribunal, it granted asylum based on the applicant's membership of the particular social group 'women in $\mathrm{PNG}^{\prime}$. This was largely based on country information citing the pervasive gender discrimination and tacit acceptance of domestic violence by PNG authorities.

In Case 2, it was necessary to tailor the concept of PSG to the facts of the case, as the evidence required to claim a broader PSG, as in Case 1, simply did not exist. The tribunal relied on in-country reports from Amnesty International and US State Departments, alongside local news reports covering incidents of domestic violence, incest and racial discrimination of Indian-Fijians to piece together the extremely narrow PSG of 'unprotected single Indian Fijian women with no family support'. This was despite the applicant herself failing to submit a claim to a PSG in the first instance, demonstrating a willingness on the part of the Refugee Review Tribunal to assist victims of domestic violence with their asylum claims to the limit of the legislative requirements.

\section{Practical Challenges of the Australian Approach}

Australia's broad approach to assessing asylum claims made by victims of domestic violence, while simultaneously widening the scope for such claims has created a number of practical difficulties for claimants. The case-by-case assessment policy requires extensive research by the decision-maker or tribunal into both the personal situation of the applicant and the context in which they are making their claim. The Australian Law Reform Commission (ALRC) states that such a rigorous process 'may be difficult for those who face language barriers, lack legal representation, or lack access to current country information' ${ }^{62}$

Regarding membership of a PSG, the ALRC emphasises that applicants are forced to tread a line between claims that are too broad, risking ' $a$ finding that the harm feared is not motivated by their membership of a particular social group', or too narrow - risking a determination 'that the group is impermissible as it is defined by the harm feared. ${ }^{63}$ In Case 2, for example, the applicant's lack of access to legal representation meant that she was not able to submit her membership of a PSG to the tribunal at all; it had to be imputed by the tribunals on the facts of the case. ${ }^{64}$

For victims of domestic violence, recalling in detail the incidents that led to their claim may lead to an exacerbation of the trauma stemming from the original harm. In Case 2, to elucidate the facts of the claim, the tribunal needed to ask questions, including an explanation of the applicant's claims of rape, ${ }^{65}$

62 ALRC, Family Violence - A National Legal Response, Report No. 114 (2010), 545.

63 ibid.

641002732 [2012] RRTA 365 (7 February 2012) [41].

65 ibid. 
whether the applicant was raped by more than one person, ${ }^{66}$ an account of the first rape, and her activities immediately following both rapes. ${ }^{67}$ These questions proved so traumatic for the applicant that the tribunal adjourned the proceedings on four separate occasions to allow the applicant time to recover. The tribunal was presented with a professional psychological assessment stating that the applicant was suffering from post-traumatic stress disorder as a result of the abuse suffered, ${ }^{68}$ the recounting of which only caused further distress. Yet the tribunal apparently needed to ask these probing questions to assess the applicant's case, given the case-by-case assessment mandate proffered by Gleeson CJ in Khawar. This 'necessary evil' is a demonstration of the practical implications of decisions at the highest level - a flaw in a system designed to protect victims of domestic violence, exposing them to further trauma in order to have their claims assessed.

\section{Conclusion}

Instances of domestic and sexual violence by non-state actors where the state is unable or unwilling to provide effective protection to the victims are well recognised as bases for claims for asylum in Australia. The Australian judiciary is ambiguous as to any definitive ruling on the legitimacy of such claims, preferring the setting of guidelines, and a case-by-case assessment policy. This ambiguity has allowed for a degree of flexibility for decision-makers and lower courts and tribunals to grant asylum to those who may not have been able to seek it otherwise.

The key criticism with this approach is its practical effects on those claiming asylum for domestic and sexual violence, as the case-by-case assessment mandate means that the victims must once again revisit their reasons for claiming asylum in order to seek protection under Australian refugee law.

\section{Bibliography}

\section{Articles/Books/Reports}

Anker, Deborah, 'Refugee Status and Violence Against Women in the "Domestic" Sphere: The Non-State Actor Question' (2001) 15 Georgetown Immigration Law Journal 391.

66 ibid.

67 ibid., [46].

68 ibid., [60]. 
Australian Law Reform Commission (ALRC), Family Violence - A National Legal Response, Report No. 114 (2010).

, Family Violence and Commonwealth Laws - Immigration Law, Issues Paper No 37 (2011).

Bacon, Rachel \& Booth, Kate, 'Persecution by Omission: Violence by Non-State Actors and the Role of the State under the Refugees Convention in Minister for Immigration and Multicultural Affairs v Khawar' (2002) 24 Sydney Law Review 584, 600.

Cianciarule, Marisa Silenzi, 'Batterers as Agents of the State: Challenging the Public/Private Distinction in Intimate Partner Violence-Based Asylum Claims' (2012) 35 Harvard Journal of Law and Gender 117.

Edwards, Alice, 'Age and Gender Dimensions in International Refugee Law', in Erika Feller, Volker Turk and Frances Nicholson (eds), Refugee Protection in International Law: UNHCR's Global Consultations on International Protection (Cambridge University Press, 2003).

- Violence Against Women Under International Human Rights Law (Cambridge University Press, 2010) 192.

Kneebone, Susan, 'Bouncing the Ball between the Courts and the Legislature: What is the Score on Refugee Issues?' (Paper presented at the Castan Centre for Human Rights Conference 'Human Rights 2003: The Year in Review', Melbourne, 4 December 2003).

- 'Women Within the Refugee Construct: "Exclusionary Inclusion" in Policy and Practice - the Australian Experience' (2005) 17(1) International Journal of Refugee Law 7.

Mullally, Siobhan, 'Domestic Violence Asylum Claims and Recent Developments in International Human Rights Law: A Progress Narrative?' (2010) 60(2) International and Comparative Law Quarterly 459.

Roberts, Anthea, 'Gender and Refugee Law' (2002) 22 Australian Yearbook of International Law 160.

United Nations Commissioner for Refugees (UNHCR), Guidelines on International Protection: 'Membership of a Particular Social Group' Within the Context of Art. IA(2), UN doc. HCR/GIP/02/02, 7 May 2002.

\section{Cases}

1002732 [2012] RRTA 365 (7 February 2012). 
The ANU Undergraduate Research Journal

1200137 [2012] RRTA 779 (1 October 2012).

Applicant A v Minister for Immigration and Ethnic Affairs (1997) 190 CLR 22.

Applicant S v Minister for Immigration and Multicultural Affairs (2004) 217 CLR 387.

Canada (Attorney General) v Ward (1993) 2 SCR 689.

Islam (AP) $v$ Secretary of State for the Home Department Regina $v$ Immigration Appeal Tribunal and Another Ex Parte Shah (AP) (Conjoined Appeals) [1999] 2 AC 629.

Matter of $R-A-$, Respondent 24 I\&N Dec. 629 (A.G. 2008).

Mayers and Marcel v MEI (1992), 97 DLR (4th) 729 (FCAD).

Minister for Immigration and Multicultural Affairs v Cali [2000] FCA 1026.

Minister for Immigration and Multicultural Affairs v Khawar (2002) 210 CLR 1.

Minister for Immigration and Multicultural Affairs v Ndege (2000) 59 ALD 758.

Refugee Appeal No. 71427/99 (NZ) [2000] INLR 608.

SZAIX $v$ Minister for Immigration and Multicultural and Immigrant Affairs [2004] FCA 104.

SZAQK $v$ Minister for Immigration and Multicultural and Immigrant Affairs [2004] FMCA 407.

Thalary v Minister for Immigration and Ethnic Affairs (1997) 72 FCR 437.

\section{Legislation}

Migration Act 1958 (Cth).

\section{Treaties}

Convention Relating to the Status of Refugees, opened for signature 28 July 1951, 189 UNTS 150 (entered into force 22 April 1954).

\section{Other}

Department of Immigration and Border Security, 'PAM3 Guidelines: Gender-Related Asylum Claims'.

Explanatory Memorandum, Migration Legislation Amendment Bill (No. 6) 2001 (Cth). 
This text taken from The ANU Undergraduate Research Journal Volume Five 2013, published 2014 by ANU Press, The Australian National University, Canberra, Australia. 